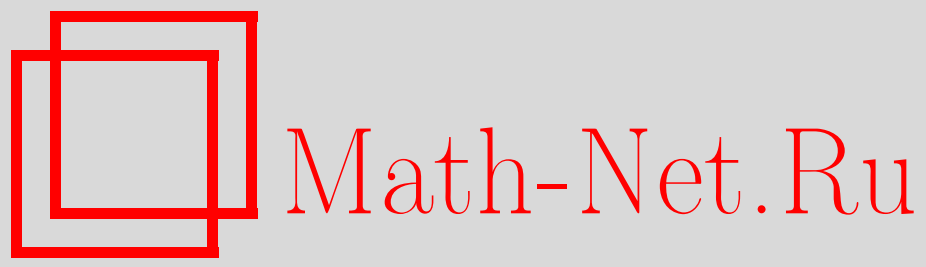

Акива Моисеевич Яглом (некролог), Теория вероятн. и ее примен., 2008, том 53, выпуск 1, 151-152

DOI: https://doi.org/10.4213/tvp2487

Использование Общероссийского математического портала Math-Net.Ru подразумевает, что вы прочитали и согласны с пользовательским соглашением

http://www . mathnet.ru/rus/agreement

Параметры загрузки:

IP : 54.81 .137 .203

26 апреля 2023 г., 16:21:06

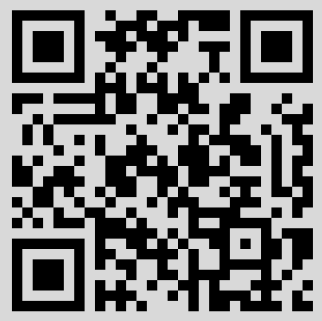




\section{ТЕОРИЯ ВЕРОЯТНОСТЕЙ}

Том 53

И ЕЕ ПРИМЕНЕНИЯ

Выпуск 1

2008

(c) $2008 \Gamma$.

ПАМЯТИ А.М. ЯГЛОМА (1921-2007)

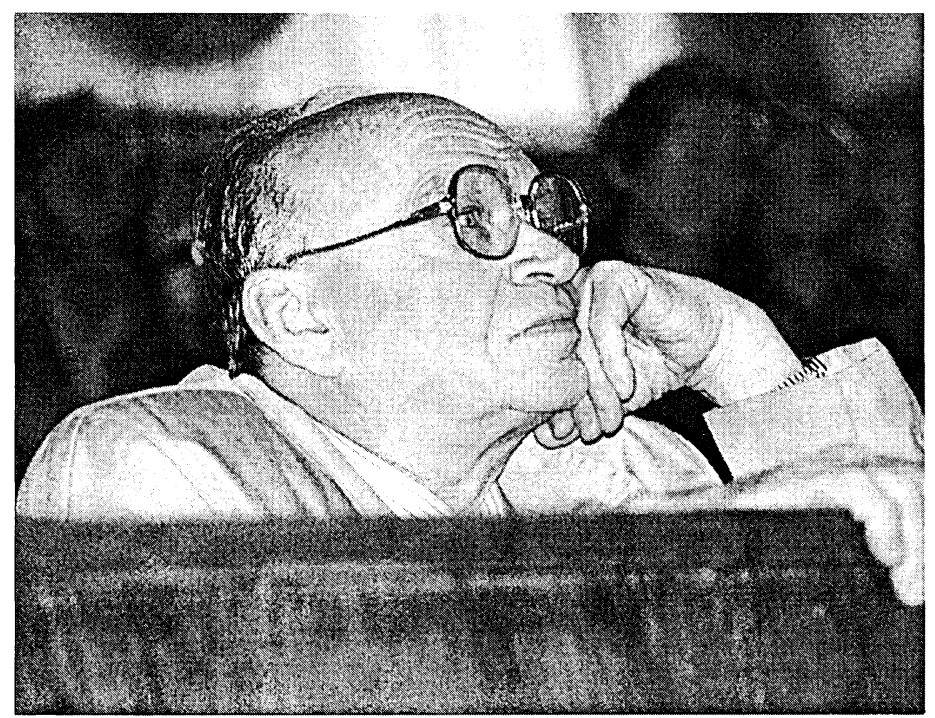

В Бостоне на 87-м году жизни скончался Акива Моисеевич Яглом, замечательный ученый, представитель того яркого периода в развитии отечественных физико-математических наук, который начинается в восстановительный период после Великой Отечественной войны.

В 1943 году А. Н. Колмогоров, который помнил братьев Яглом как победителей Московской математической олимпиады школьников 1938 г., предложил Акиве Моисеевичу поступить в аспирантуру Математического института им. В. А. Стеклова. Одновременно Акива Моисеевич начал работать на кафедре теории вероятностей МГУ, возглавляемой А.Н. Колмогоровым. В 1946 г. Акива Моисеевич окончил аспирантуру и успешно защитил кандидатскую диссертацию на тему «О статистической обратимости брөуновского движения». Оппонентами по этой диссертации были М. А. Леонтович и А.Я. Хинчин. В эти годы Акива Моисеевич увлекся теоретической физикой: еженедельно посещал семинары Л.Д. Ландау и И.Е. Тамма, вместе с И. М. Гельфандом пытался найти уравнение элементарных частиц с высшими спинами. Однако в конечном счете приглашение И.Е. Тамма и В.Е. Гинзбурга в теоретический отдел ФИАН так и не было реализовано, и А. М. Яглом поступил во вновь созданную (по инициативе А. М. Обухова, поддержанной академиками А.Н. Колмогоровым и О. Ю. Шмидтом) Лабораторию атмосферной турбулентности Института 
теоретической геофизики АН СССР. В итоге он проработал в Лаборатории атмосферной турбулентности (сперва в ИТГ, затем в Геофиане, затем в Институте физики атмосферы) более 45 лет.

В 1955 году Акива Моисеевич защитил докторскую диссертацию «Теория корреляции непрерывных процессов и полей с приложениями к задачам статистической экстраполяции временных рядов и к теории турбулентности». Он является автором 150 статей и 7 книг, из которых две - двухтомники. Особо следует отметить выдаюшуюся монографию «Статистическая гидромеханика» (2 тома, 1965 г., совместно с А.С. Мониным). До последних дней, уже живя в США, Акива Моисеевич работал над ее новым изданием - фактически новой книгой, основанной на теоретических и экспериментальных результатах за последние 35 лет. В 1988 г. А. М. Яглом был удостоен премии имени Лапорта Американского физического общества, а в 2007 г. Европейский союз по наукам о Земле присудил ему медаль Ричардсона.

Акива Моисеевич был энциклопедически образован во многих вопросах культуры. Он знал до мельчайших деталей историю от античных до недавних времен. Его библиотека поражала не только своим объемом, но и диапазоном тем. Столь же непринужденно он ориентировался и в других видах искусства. Его замечания о драматических, оперных и балетных спектаклях всегда были точными и меткими.

При этом Акива Моисеевич оставался неизменно доброжелательным и отзывчивым человеком, всегда готовым поделиться неисчерпаемым запасом знаний. В свои школьные годы А. М. Яглом, вместе с братом-близнецом Исааком Моисеевичем, которого он пережил почти на 20 лет, был среди первьгх московских кружковцев и олимпиадников. Впоследствии их научно-популярные книжки «Геометрические преобразования», «Неэлементарные задачи в элементарном изложении», «Вероятность и информация», ... пользовались любовью и популярностью и привлекли к математике несколько следующих поколений школьников.

Светлая память об Акиве Моисеевиче Ягломе сохранится в сердцах его близких, друзей и коллег. 